\title{
PERSEPSI DAN AKSI MASYARAKAT PEDESAAN DI MASA PANDEMI
}

\author{
Chusna Apriyanti ${ }^{*}$, Riza Dwi Tyas Widoyoko ${ }^{1}$ \\ ${ }^{1}$ STKIP PGRI Pacitan, Indonesia \\ *e-mail: chusna.apriyanti@gmail.com
}

\begin{abstract}
Abstrak
Data statistik dari Satgas Penanganan COVID-19 Indonesia menunjukkan kenaikan pasien yang signifikan. Akan tetapi, kesadaran masyarakat untuk mematuhi protokol kesehatan semakin berkurang dan abai. Penelitian ini bertujuan untuk mengkaji persepsi dan aksi masyarakat pedesaan dalam kehidupan seharihari selama pandemi COVID-19 di Pacitan dan faktor yang mempengaruhinya. Banyak riset yang mengulas tentang sikap masyarakat dalam menghadapi pandemi, namun penelitian ini berfokus pada masalah masyarakat pedesaan karena mereka menganggap wilayahnya aman sehingga menyepelekan protokol kesehatan. Penelitian ini menggunakan desain deskriptif kualitatif. Data diperoleh dengan melibatkan 51 responden dari 51 dusun di Kabupaten Pacitan. Responden tersebut bertindak sebagai observer bagi lingkungan masyarakatnya. Satu orang responden mengamati 10 orang di sekitar tempat tinggalnya. Sehingga jumlah sampel penelitian berjumlah 510 orang. Data diambil menggunakan lembar observasi yang dilaporkan secara online menggunakan google form. Data dianalisis dengan cara menghitung hasil angket, menganalisis data, menyajikan data, melakukan telaah mendalam, dan membuat kesimpulan. Hasil menunjukkan bahwa persepsi dan aksi masyarakat di pedesaan dalam menghadapi pandemi COVID-19 menunjukkan tingkat kesadaran, kepatuhan, dan konsistensi yang masih rendah. Penelitian menemukan hanya $13.7 \%$ masyarakat yang konsisten menggunakan masker terutama ketika beraktivitas di luar rumah. Penerapan physical distancing menunjukkan sebanyak $56.9 \%$ masyarakat masih beraktivitas dan berkumpul di luar rumah. Pada aspek ketersediaan sarana cuci tangan menunjukkan ada sebanyak $31.4 \%$ rumah tidak menyediakan sarana cuci tangan. Berbagai faktor dan persepsi yang mempengaruhi persepsi dan aksi masyarakat di masa pandemi mencakup kurangnya pemahaman akan COVID-19, rendahnya partisipasi masyarakat untuk ikut serta dalam upaya pencegahan COVID-19, kondisi ekonomi masyarakat dan tidak adanya aturan yang mengikat.
\end{abstract}

Kata kunci: Persepi; Aksi; Masyarakat Perdesaan; Pandemi COVID-19

\begin{abstract}
Statistical data from the Indonesian COVID-19 Response Task Force shows a significant increase in the number of patients. However, public awareness to comply with health protocols is diminishing and ignorant. The research aimed to know the community's reactions and actions in dealing with COVID-19 in rural areas in Pacitan and the influencing factors. Many studies analyzed people's attitudes toward the pandemic, but this research focused on rural communities' problems because they believe that their villages are safe, which undermines the health protocols. This research used a qualitative descriptive design by involving 51 respondents from 51 villages in Pacitan Regency. The respondent acts as an observer for the community environment. One respondent observed ten people in his neighborhood. Therefore, the number of research samples was 510 people. Data were taken using an observation sheet that was reported online using Google form. Data were analyzed by calculating the results of the questionnaire, analyzing the data results,
\end{abstract}


presenting the data, conducting an in-depth study, and making conclusions. The results showed that people's reactions and actions in rural areas in the face of the COVID-19 pandemic still showed a low level of awareness, compliance, and consistency. The study found that only $13.7 \%$ of the people consistently used masks, especially when doing activities outside the home. The physical distancing application showed that $56.9 \%$ of the community is still active and gathering outside the home. Regarding the availability of handwashing facilities, there are still $31.4 \%$ of houses that do not provide handwashing facilities. Various factors and perceptions influenced people's reactions and actions during the pandemic: lack of understanding of COVID-19, low community participation to participate in efforts to prevent COVID-19, community economic conditions, and absence of binding rules.

Keywords: Perception; Action; Rural Community COVID-19 Pandemic

This is an open access article under the CC BY-SA license.

Copyright @ 2021 by Author. Published by Universitas Pendidikan Ganesha.

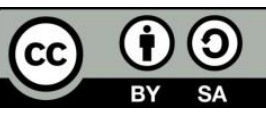

\section{PENDAHULUAN}

Sejak ditemukan pada akhir Desember 2019 di Wuhan China, kasus Coronavirus Disease atau yang disebut dengan COVID-19 semakin merebak ke seluruh penjuru dunia. Bahkan, pada tanggal 11 Maret 2020, WHO secara resmi menyatakan COVID-19 sebagai pandemi karena dalam waktu kurang dari tiga bulan telah menginfeksi lebih dari 126.000 orang di 123 negara dari Asia, Eropa, AS, hingga Afrika Selatan (Putri, 2020). Di Indonesia sendiri, kasus pertama COVID-19 ditemukan pada hari Senin, 2 Maret 2020 (Detik.com, 2020) dan semakin bertambah dari hari ke hari. Bahkan, terjadi lonjakan yang sangat signifikan setelah lebaran Idul Fitri $1441 \mathrm{H}, 24$ Mei lalu. Ada tambahan 479 pasien positif pada Senin, 25 Mei 2020 atau hari kedua lebaran hingga pukul 12.00 sehingga total menjadi 22.750 (Adib Auliawan, 2020). Saat ini, Indonesia menduduki posisi kedua setelah Singapura sebagai negara dengan jumlah kasus terbanyak COVID19. Namun meskipun di bawah Singapura, Indonesia tercatat sebagai negara dengan kematian tertinggi kasus COVID-19.

Melihat kasus tersebut, pemerintah Indonesia telah melakukan berbagai macam cara, mulai dari PSBB sampai larangan mudik untuk perayaan hari raya. Pemerintah juga tidak hentihentinya untuk melakukan kampanye pencegahan penyebaran COVID-19 dengan cara jaga jarak, memakai masker jika keluar rumah, sering cuci tangan pakai sabun, dll. tidak hanya berhenti sampai disitu, pemerintah mulai menutup kantor-kantor nonvital, mall dan tempat hiburan, tempat pariwisata, dan sekolah. Dengan harapan, akan sedikit masyarakat yang berinteraksi yang ditakutkan akan menambah jumlah penyebaran COVID-19. 
Namun, kebijakan tersebut belum berbanding lurus dengan apa yang terjadi di lapangan. Banyak berbagai sumber berita yang menyatakan bahwa pasar masih ramai, mall pun masih terdapat kerumunan warga. Warga seakan tidak "satu kata" untuk benar-benar mampu bertahan di rumah sampai wabah benar-benar berhenti. Bagaimanapun aturan dibuat, jika partisipasi masyarakat masih rendah dalam melaksanakan aturan tersebut, kemungkinan penyebaran COVID-19 belum bisa berkurang dalam waktu dekat.

Rendahnya partisipasi masyarakat dalam mengikuti aturan yang ditetapkan memang berasal dari banyak alasan. Alasan paling utama adalah masalah ekonomi. Banyak warga yang nekat untuk bekerja karena tidak ada jaminan pendapatan yang stabil di tengah pandemi terutama mereka yang bekerja harian. Banyak warga yang terpaksa tetap bekerja agar bisa mencukupi kebutuhan hidupnya. Meskipun hal ini tidak serta-merta bisa menjadi alasan karena pemerintah sudah mengucurkan beberapa bantuan sosial kepada masyarakat dengan skim yang bermacam-macam.

Partisipasi dan peran masyarakat menjadi formula penting dalam pencegahan penyebaran COVID-19 di seluruh wilayah Indonesia. Marston (2016) menyebutkan bahwa sejalan dengan pandangan WHO yang dalam sistem kesehatan yang disusun menyatakan bahwa masyarakat yang berdaya memegang peranan penting dalam upaya pembangunan kesehatan (Sitohang et al., 2020). Namun, seringkali masyarakat masih terlihat abai akan pandemi ini. Partisipasi yang rendah tersebut juga berkaitan dengan perasaan aman semu. Peningkatan rasa aman semu dalam masyarakat dipengaruhi oleh setidaknya tiga faktor: beragamnya persepsi masyarakat terhadap risiko penularan COVID-19, penerapan adaptasi, baik di tingkat individu maupun masyarakat, yang bersifat sementara, dan ketakselarasan kebijakan pemerintah (Fillaili \& Tamyis, 2020). Rendahnya partisipasi masyarakat dalam penerapan protokol kesehatan juga dipengaruhi oleh faktor psikologi yang disebut bias kognitif. Bias kognitif adalah kesalahan sistematis dalam berpikir yang memengaruhi keputusan dan penilaian yang dibuat seseorang (Buana, 2020). Hal ini menyebabkan kesalahan dama berpikir manusia ketika berusaha menafsirkan informasi-informasi yang muncul di sekitar mereka.

Selain itu, masyarakat juga seakan belum mampu adaptif dalam menjalani hidupnya. Terbukti dengan ditemukannya kasus penyalahgunaan dana bansos untuk membeli baju Lebaran di Bogor. Sidak dilakukan langsung oleh Walikota Bogor, Bima Arya. Dari 10 pembeli di toko pakaian, 6 diantaranya adalah penerima bansos setelah NIKnya dicocokkan dengan data 
(Sudarno, 2020). Hal ini hanya salah satu contoh saja belum meningkatnya partisipasi masyarakat dalam menghadapi pandemi. Bansos yang diharapkan mampu memberikan stabilitas ketahanan pangan justru digunakan untuk hal tersier seperti baju lebaran. Padahal, peran aktif masyarakatlah yang menjadi kunci pengendalian virus ini. The communities' responses should be seen as key to end this pandemic. They should be seen as a part of solutions and not the problem (Djalante et al., 2020).

Persepsi masyarakat pasti berbeda-beda antara satu dengan lainnya sehingga efek atau aksi yang ditimbulkan berbeda-beda. Setiap orang memiliki perbedaan cara pandang atas hal yang terjadi. Hal tersebut dipengaruhi oleh banyak faktor, seperti pengalaman, pengetahuan, latar belakang pendidikan, sosial ekonomi, budaya, usia dll. sehingga treatment masyarakat dalam mencerna informasi dan melakukan reaksi pasti berbedabeda.

Sarlito W. Sarwono (2009 dalam Rohmaul Listyana \& Yudi Hartono, 2015) berpendapat bahwa persepsi secara umum merupakan proses perolehan, penafsiran, pemilihan dan pengaturan informasi indrawi. Persepsi berlangsung pada saat seseorang menerima stimulus dari dunia luar yang ditangkap oleh organ-organ bantunya yang kemudian masuk ke dalam otak. Senada dengan hal itu Sugihartono (dalam Arifin et al., 2017) juga menyatakan bahwa persepsi merupakan kemampuan panca indera dalam menerjemahkan stimulus atau proses untuk menerjemahkan stimulus yang masuk ke dalam alat indera manusia. Dari kedua teori tersebut sangat jelas bahwa persepsi adalah penafsiran sesorang atas apa yang ia dapatkan di media.

Proses pembentukan persepsi menurut Walgito (1981) (dalam Arifin et al., 2017) dibentuk dalam tahapan berikut. 1. Tahap pertama, merupakan tahap yang dikenal dengan nama proses kealaman atau proses fisik, merupakan proses ditangkapnya suatu stimulus oleh alat indera manusia. 2. Tahap kedua, merupakan tahap yang dikenal dengan proses fisiologis, merupakan proses diteruskannya stimulus yang diterima oleh reseptor (alat indera) melalui saraf-saraf sensoris. 3. Tahap ketiga, merupakan tahap yang dikenal dengan nama proses psikologik, merupakan proses timbulnya kesadaran individu tentang stimulus yang diterima reseptor. 4. Tahap keempat, merupakan hasil yang diperoleh dari proses persepsi yaitu berupa tanggapan dan perilaku. Keempat proses itulah yang membentuk persepsi orang dalam melihat sesuatu di dunia luar sekitarnya.

Banyak riset yang telah dilakukan mengenai persepsi masyarakat selama pandemi COVID-19 ini, namun riset ini fokus pada persepsi dan aksi 
masyarakat pedesaan selama pandemi COVID-19. Observasi dilakukan selama minggu terakhir bulan Mei tahun 2020 di Pacitan. Berdasarkan observasi, masyarakat di pedesaan masih melakukan ritual kunjung-mengunjungi. Tidak hanya sampai di situ, kebiasaan ngabuburit pun masih terjadi di sore hari. Berbeda dengan masyarakat di pusat kota Pacitan, masyarakat di pedesaan belum melakukan PHBS dengan baik seperti yang dianjurkan oleh pemerintah. Penelitian ini bertujuan untuk melihat bagaimana persepsi dan aksi masyarakat pedesaan dalam kehidupan sehari-hari selama pandemi COVID-19.

\section{METODE}

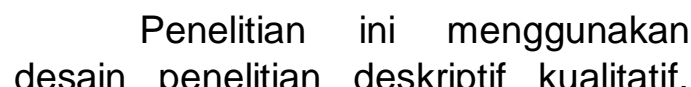
Penelitian dilakukan di desa-desa di Pacitan dengan melibatkan 51 responden yang bertindak sebagai observer dalam aksi masyarakat di lingkungan sekitarnya. Peneliti menggunakan teknik kuota sampling dalam memilih responden sebagai observer. Reponden berjumlah 51 orang. Setiap satu responden harus mengamati 10 warga sekitarnya. Sehingga jumlah keseluruhan responden 510 orang.

Observer

kedisplinan masyarakan menggunakan masker, aktivitas kerumunan wara, kebijakan pemerintah setempat tentang pencegahan COVID-
19, dan fasilitas protokol kesehatan. Penelitian ini dilakukan dari tanggal 20 Mei sampai 27 Mei 2020.

Tahapan pengumpulan dan analisis data dalam penelitian ini adalah sebagai berikut: observer melakukan observasi lapangan, observer melaporkan hasil observasi menggunakan Google Form, peneliti merekap data yang diinput oleh observer, peneliti menginterpretasikan data, dan membuat kesimpulan.

\section{HASIL DAN PEMBAHASAN} Pemakaian Masker

Masker merupakan alat pelindung diri yang wajib dipakai oleh seluruh warga masyarakat. Namun, menurut observasi dalam penelitian ini, tidak semua masyarakat memiliki kesadaran untuk menggunakan masker.

Berikut hasil dari pengamatan di lapangan.

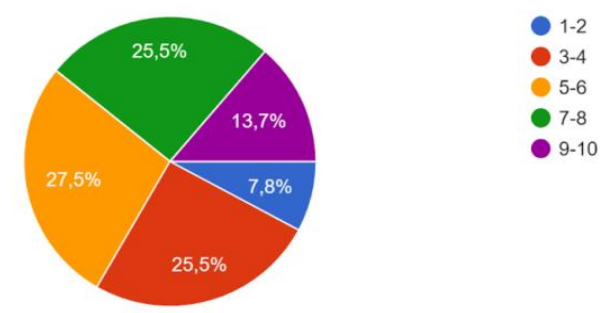

Gambar 1. Jumlah Masyarakat yang Menggunakan Masker

Dari 10 orang yang diobservasi oleh responden, terdapat 5 klasifikasi tingkatan penggunaan masker, yaitu: $7.8 \%$ responden menyatakan bahwa dari 10 orang yang diobservasi, hanya 1-2 orang yang menggunakan masker; 
$25.5 \%$ responden menyatakan bahwa dari 10 orang yang diobservasi, hanya 3-4 orang yang menggunakan masker; $27.5 \%$ responden menyatakan bahwa dari 10 orang yang diobservasi, terdapat 5-6 orang yang menggunakan masker; $25.5 \%$ responden menyatakan bahwa dari 10 orang yang diobservasi, terdapat 7-8 orang yang menggunakan masker; sedangkan $\quad 13.7 \% \quad$ responden menyatakan bahwa dari 10 orang yang diobservasi, terdapat 9-10 orang yang menggunakan masker. Angka-angka ini menunjukkan bahwa kesadaran menggunakan masker oleh masyarakat masih rendah meskipun secara pengetahuan mereka mengerti manfaat menggunakan masker selama masa pandemi. Pengetahuan ini seharusnya memberi dampak singnifikan terhadap tingginya kesadaran penggunaan masker sebab terdapat hubungan antara pengetahuan masyarakat dengan kepatuhan menggunakan masker sebagai upaya pencegahan penyakit Covid-19 (Devi Pramita Sari \& Nabila Sholihah 'Atiqoh, 2020).

Rendahnya penggunaan masker ini disebabkan oleh beberapa hal. Pertama, mereka menganggap bahwa lingkungan desa sangat aman. Aktivitas yang mereka lakukan pun hanya sebatas di lingkungan sekitar mereka. Anggapan tersebut belum tentu benar karena masyarakat masih bergantung pada suplai sayur dari pasar besar. Bisa saja pedagang tersebut membawa virus ke pedesaan. Beberapa waga juga masih berbelanja di pusat kota kecamatan yang ramai. Tentunya penyadaran bahwa penggunaan masker berlaku untuk seluruh warga harus ditingkatkan.

Alasan lainnya berkaitan dengan kebiasaan tanpa penggunaan masker. Warga tidak terbiasa memakai masker sehingga masker membuat tidak nyaman dan mengganggu keseharian masyarakat.

\section{Physical Distancing}

Pemahaman umum akan pentingnya penerapan physical atau social distancing dalam menangani wabah tidak mampu mengontrol masyarakat agar berperilaku sesuai dengan persepsi umum tersebut. Seseorang bisa saja berpersepsi bahwa kebijakan physical atau social distancing sangat penting, namun tidak dapat menahan diri untuk keluar rumah guna berbagai kepentingan (Novira et al., 2020). Temuan ini juga terbukti dalam penelitian ini dengan fakta bahwa masih banyak warga yang beraktivitas di luar rumah seperti terlihat pada Gambar 2.

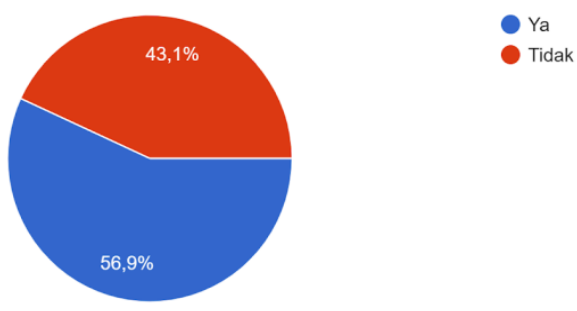

Gambar 2. Jumlah Warga yang Masih Berkerumun di luar Rumah.

Jurnal IImu Sosial dan Humaniora | 55 
Gambar 2 tersebut menyatakan bahwa sebanyak $56.9 \%$ masyarakat masih berkerumun dan $43.1 \%$ responden menyatakan bahwa sudah tidak ada kegiatan di luar rumah yang melibatkan kerumunan masyarakat. Kegiatan yang mengakibatkan kerumunan massa tersebut terjadi karena lingkungan masyarakat masih mengadakan kegiatan seperti kenduri, ronda malam, dan cangkrukan seperti yang tersaji pada Gambar 3.

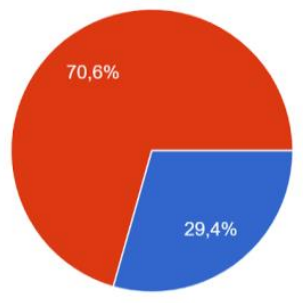

Gambar 3. Jumlah Masyarakat yang Masih Melakukan Kenduri, Ronda Malam/Cangkrukan

Dari Gambar 3 sangat jelas bahwa sebanyak 29.4 responden mengatakan bahwa di lingkungan sekitarnya masih terdapat kegiatan yang melibatkan berkumpulnya massa seperti kenduri, ronda malam, dan cangkrukan sedangkan sebanyak 70.6 responden mengaku bahwa di daerahnya sudah tidak terdapat kegiatan semacamnya.

Warga yang masih melakukan kenduri dan semacamnya mengaku bahwa hal tersebut aman karena yang datang adalah masyarakat sekitar tempat tinggal. Ronda malam dan cangkrukan pun masih terjadi karena merupakan kebiasaan yang sudah dilakukan sejak lama. Cangkrukan dilakukan di warung warga dan pos ronda. Hal ini tentunya harus dihindari meskipun teman berkumpul merupakan tetangga sekitar tempat tinggal karena tetangga tersebut pun masih berkegiatan diluar desa sehingga kemungkinan terpapar virus masih ada.

Puncak kegiatan berkumpulnya massa terjadi pada momen hari raya idul fitri. Dari hasil observasi, sebanyak $60.8 \%$ responden masih melihat bahwa masyarakat masih saling mengunjungi selama hari raya dan sebanyak $39.2 \%$ responden mengaku bahwa di sekitarnya tidak terdapat aktivitas saling mengunjungi selama hari raya.

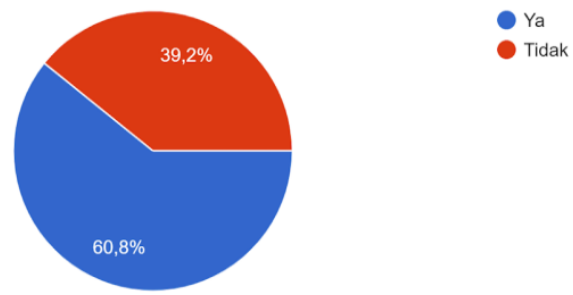

Gambar 4. Jumlah Masyarakat yang Saling Berkunjung pada Hari Raya

\section{Protokol Kesehatan}

Berdasarkan jelasan di atas bisa dilihat bahwa setiap daerah memiliki kebijakan daerah sendiri yang mungkin disepakati oleh masyarakat desa maupun RT dan RW setempat. Namun, sayangnya tidak semua daerah memiliki kebijakan yang sama terhadap upaya pencegahan

Jurnal IImu Sosial dan Humaniora | 56 
COVID-19 ini seperti yang tersaji pada Gambar 5.

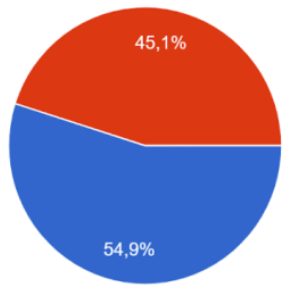$$
\text { Tidak }
$$

Gambar 5. Jumlah Dusun/Desa yang Memiliki Kebijakan Tentang Pencegahan COVID-19

Berdasarkan gambar 5 tesebut sangat jelas bahwa sebanyak $45.1 \%$ daerah (dusun/desa) tidak memiliki aturan tertulis khusus yang dibuat oleh pemerintah desa/dusun dalam upaya pencegahan COVID-19 dan sebanyak $54.9 \%$ mempunyai aturan khusus tertulis yang diwajibkan dipatuhi oleh seluruh warga masyarakat. Kebijakan tersebut merupakan implementasi kebijakan detail dari pemerintah daerah di atasnya seperti pemerintah daerah kecamatan, kabupaten atau propinsi.

\section{Tersedianya Sarana Cuci Tangan}

51 responden menyatakan dari 10 rumah yang diobservasi, terdapat $31.4 \%$ tidak memiliki sarana cuci tangan di depan rumah dan $68.6 \%$ menyatakan bahwa mereka memiliki sarana cuci tangan di depan rumah.

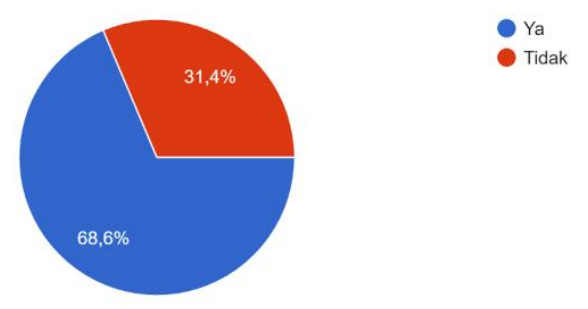

Gambar 6. Jumlah Rumah yang Memiliki Sarana Cuci Tangan di Depan Rumah

Berdasarkan hasil observasi sangat jelas bahwa tidak semua masyarakat memiliki kesadaran untuk menggunakan masker ketika mereka keluar rumah. Hanya 13.7\% masyarakat yang konsisten menggunakan masker ketika keluar rumah. Setelah dilakukan penyelidikan, mereka mengaku bahwa tujuan mereka keluar rumah hanya sebentar dan dalam jarak yang dekat. Mereka hanya pergi ke warung dan membeli sayur di pedagang sayur keliling. Padahal, hal ini tidak mengurangi risiko penyebaran virus meskipun mereka hanya membeli sayur di pedagang sayur keliling. Bisa saja pedagang sayur keliling tersebut sudah berkeliling ke banyak tempat dan berinteraksi dengan banyak orang yang tidak bisa dijamin terbebas dari virus. Dengan demikian walaupun aktivitas hanya dilakukan di depan rumah, pemakaian masker tetap menjadi kebutuhan yang utama.

Dari pantauan, para pemuda yang melakukan ngabuburit di jalanjalan saat bulan puasa juga tidak memakai masker. Mereka beralasan 
bahwa mereka hanya berada di daerah lokal dan tidak bepergian keluar kota atau daerah zona merah. Mereka hanya berhenti jika pihak aparat menertibkan mereka. Kelompok paling besar yang tidak memakai masker adalah para pekerja di sawah dan ladang. Mereka beralasan bahwa pemakaian masker tidak nyaman untuk melakukan kegiatan. Mereka juga berpendapat bahwa mereka tidak berinteraksi dengan banyak orang jadi tidak ada kemungkinan terpapar virus. Mereka juga belum terbiasa dengan pemakaian masker. Padahal pihak desa sudah membagikan masker gratis untuk para warganya agar mereka tidak kesulitan mendapatkan masker. Namun langkah ini belum serta-merta diikuti oleh seluruh warga masyarakat.

Selain kewajiban menggunakan masker oleh masyarakat, masyarakat juga harus menjaga jarak dengan orang lain. Ketika keluar rumah, paling tidak harus berjarak sejauh 1-2 meter agar bisa meminimalkan dampak penularan virus COVID-19. Dengan jarah sejauh itu diharapkan orang akan terhindar dari droplet yang mungkin dikeluarkan oleh orang yang terkonfirmasi positif COVID19. Namun sayangnya tidak semua orang sadar akan pentingnya jaga jarak. Terbukti dari observasi yang dilakukan oleh responden terhadap wilayah sekitarnya. Dari hasil observasi, sebanyak $56.9 \%$ masyarakat masih berkumpul di luar rumah. Tentunya ini sangat berisiko terhadap penularan virus COVID-19. Lebih diperparah lagi jika mereka berkumpul tanpa berjarak dan tanpa menggunakan masker seperti jika mereka berada di warung makan atau warung kopi. Di pusat kabupaten memang tempat makan atau restoran hanya menerima orderan deliveri atau makan di rumah saja. Namun beberapa warung kecil di desa masih buka sehingga memungkinkan untuk warga mengobrol sambil nongkrong di warung tersebut.

Kebiasaan warga untuk nongkrong tidak hanya di warung, namun juga di tempat ronda. Tragisnya, posko yang dibuat dengan tujuan untuk memeriksa warga yang masuk ke desa tersebut malah digunakan untuk nongkrong. Ini menjadi ironi. Harusnya portal penjagaan untuk keluar masuk daerah hanya dijaga sedikit orang bukan digunakan untuk nongkrong bersama. Tidak berhenti sampai disitu, dari observasi sebanyak 29.4 responden mengaku masih melihat diadakannya kegiatan berkumpul massa seperti kenduri atau selamatan dan kegiatan lainnya. Mereka berpendapat bahwa karena hidup di desa, mereka tidak memiliki potensi yang besar untuk terpapar virus. Namun sayangnya tidak semua warga memiliki persepsi dan awareness yang sama terhadap virus, bahkan ketika ada tokoh masyarakat yang mengingatkan tentang protokol kesehatan, banyak warga yang tidak mengindahkannya.

Jurnal IImu Sosial dan Humaniora | 58 


\begin{abstract}
Pada perayaan hari raya idul fitri pun masyarakat masih saling mengunjungi ke rumah tetangga atau sanak saudara meskipun tingkat lokal daerah, namun tetap saja hal tersebut sebaiknya perlu diwaspadai. Sebanyak $60.8 \%$ responden mengaku di daerahnya masih terdapat tradisi saling mengunjungi saat hari raya. Hal ini terjadi karena sudah menjadi adat istiadat bagi mereka. Bahkan saat bulan ramadhan pun mereka mayoritas masih melaksanakan tarawih berjamaah di masjid meskipun di beberapa daerah sudah mengatur shafnya menjadi lebih berjarak.
\end{abstract}

Dari hasil observasi, dalam perayaan hari raya dan aktivitas saling mengunjungi, hanya sedikit warga yang sadar untuk mencuci tangan dahulu sebelum masuk ke rumah tetangga. Alasan lainnya karena mereka berpendapat bahwa kunjungan hanya dilakukan sebentar dan tidak sampai menikmati kudapan, mereka hanya masuk dan berjabat tangan lalu keluar. Meskipun beberapa orang tidak melakukan jabat tangan secara langsung. Hal tersebut lebih diperparah lagi dengan tidak tersedianya sarana cuci tangan bagi sebagian rumah. Dari hasil observasi, sebanyak $31.4 \%$ rumah tidak menyediakan sarana cuci tangan untuk tamu. Hal ini jelas-jelas melanggar protokol kesehatan yang sudah diatur oleh pemerintah.

Melihat kondisi di lapangan seperti ini, jelas bahwa pemerintah daerah harus mengambil langkah penting agar wabah pandemi ini cepat berlalu. Utamanya terkait peraturan, kebijakan atau regulasi. Hal menjadi sangat penting, Hamzah (2020) menjelaskan bahwa salah satu kunci dalam menghentikan penyebaran Covid-19 ini adalah melalui kebijakan dan regulasi. Langkah kebijakan yang dilakukan adalah pertama, adanya payung hukum yang jelas (norm). Kedua, adanya Produk hukum sebagai langkah teknis dari paying hukum yang sudah ada (instrument). Dan ketiga, adanya perlindungan hukum (waarborg) bagi semua stakeholder dalam proses pencegahan dari penyebaran Covid-19 ini (Hasrul, 2020). Namun berdasar hasil temuan, hanya $54.9 \%$ pemerintah desa atau dusun yang memiliki aturan khusus untuk warganya tentang upaya pencegahan COVID-19 ini. Peraturan lokal desa sangat penting karena tidak semua masyarakat desa paham dan mengerti akan aturan dari pemerintah pusat seperti kebijakan tentang silaturahmi di hari raya. Pemerintah tingkat kabupaten melalui Kementerian Agama kabupaten sudah membuat peraturan bahwa "Silaturahmi bisa dilakukan melalui media sosial dan video call atau video conference." Tentu hal ini sudah sangat lazim dipahami oleh masyarakat dengan pengetahuan akan gawai dan teknologi sudah baik. Memang mayoritas masyarakat sudah memiliki perangkat yang memungkinkan untuk silaturahmi virtual, namun dengan 
kalimat yang kurang mengikat untuk larangan silaturahmi secara langsung masih memungkinkan bagi masyarakat untuk saling mengunjungi saat hari raya. Tidak heran jika masyarakat kadang tidak disiplin dalam menjalankan protokol kesehatan.

Dengan aturan tersebut, sudah selayaknya pemerintah desa yang memiliki kewenangan untuk membuat aturan lebih mengikat dengan melihat karakteristik daerahnya sendiri. Seperti halnya larangan tegas untuk tidak saling berkunjung saat hari raya, larangan untuk aktivitas atau kegiatan yang membuat berkumpul atau berkerumunnya massa, larangan mengadakan hajatan dll. tentunya masyarakat pun juga lebih mudah memahami aturan jika aturan tersebut dibuat oleh orang yang dekat dan mereka pahami. Hal ini penting karena apa yang terjadi di desa satu berbeda dengan desa yang lain. Jika misalnya desa A merupakan daerah zona merah dengan adanya warga yang terkonfirmasi positif tentu berbeda treatmentnya dengan desa $B$ yang mungkin masuk zona kuning. Contoh aturan pemerintah desa bisa dilihat dalam Gambar 7.

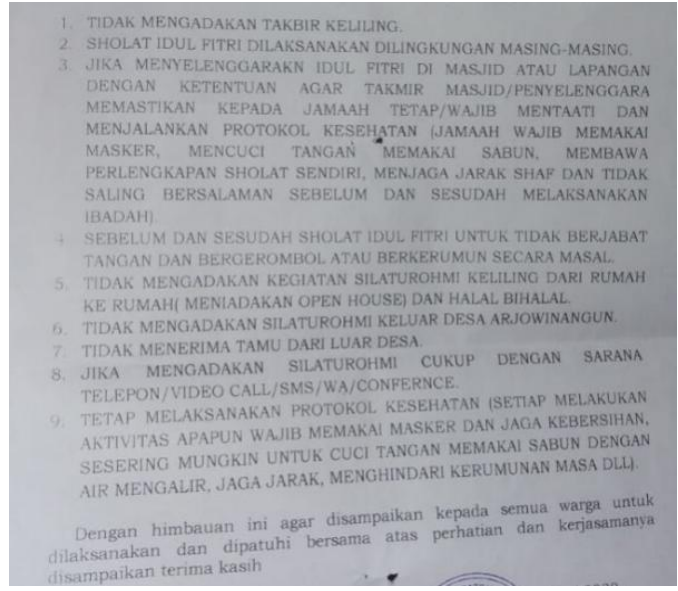

Gambar 7. Peraturan Desa

Gambar 7 tersebut merupakan contoh aturan desa yang wajib dipatuhi oleh seluruh warga desa. Aturan tersebut sifatnya memaksa dan mengikat sehingga masyarakat diharuskan untuk mematuhinya. Selain sangat tegas, peraturan tersebut juga sangat detail mengatur seluruh hajat hidup masyarakat berkenaan dengan upaya pencegahan COVID-19 di daerahnya. Jika semua desa memiliki peraturan seperti ini dengan kewajiban menjalankan bagi seluruh warga desanya tentu mampu mendisiplinkan warga desa agar tidak melanggar protokol kesehatan dan membahayakan baik dirinya maupun lingkungannya. Dengan adanya peraturan seperti di atas, warga masyarakat juga satu kata yang padu dengan pemerintah desa dalam memerangi COVID-19 sehingga tidak terdapat silang pendapat dan miskomunikasi antar pemerintah desa dan warga masyarakat.

Jurnal IImu Sosial dan Humaniora | 60 
Faktor yang Mempengaruhi Persepsi dan Aksi Masyarakat dalam Upaya Pencegahan COVID-19

\section{Kurangnya Pemahaman akan COVID- 19}

Abdul et al., (2020) mengungkapkan secara luas terdapat prediktor yang bersifat multilevel dalam menjelaskan ketidakpatuhan masyarakat terhadap aturan dan himbauan pemerintah di masa pandemi Covid-19. Di level individu, mencakup aspek psikologis seperti ideologi, harapan, religious coping, psychological well-being, pengetahuan dan pengalaman, serta komitmen terhadap kesejahteraan sosial. Di level kelompok, meliputi penerimaan sosial, kondisi ekonomi, dan budaya kolektif. Di level society, mencakup persepsi terhadap pemerintah.

Pemahaman akan adanya virus COVID-19 ini menjadi titik pokok dan dasar dalam upaya pencegahan COVID-19 di masyarakat. Peneliti menyadari bahwa kondisi masyarakat pedesaan sangat berbeda dengan masyarakat perkotaan berkenaan dengan alur informasi dan komunikasi. Jika di daerah perkotaan, masyarakat sudah memiliki perangkat elektronik yang memadai dengan sinyal internet yang begitu mudah dijangkau. Belum lagi banyak akses WIFI yang bisa digunakan untuk mengais informasi dari dunia maya. Hal ini tentu berbeda dengan masyarkat pedesaan dengan minimnya akses informasi dan komunikasi. Mereka memang sudah memiliki gawai, namun sinyal internet tidak mampu menjangkau seluruh daerah pedesaan apalagi mereka tinggal di daerah pegunungan atau daerah dataran tinggi. Tidak heran jika akses informasi menjadi tersendat. Televisi pun bisa diakses dengan menggunakan parabola khusus karena tidak terjangkau dan tidak bisa mendapatkan sinyal jika hanya memakai antena. Hal tersebut tentunya berpengaruh pada persepsi dan sikap dalam mengolah informasi tentang COVID-19 yang beredar yang mempengaruhi tingkat pemahaman individu. Belum lagi jika informasi tersebut bercampur antara hoax dan fakta. Faktanya, tidak semua warga masyarakat bisa membedakan mana informasi yang hoax dan fakta. Beberapa penyebab menurut Heidi Larson, karena banyak informasi yang saling bertentangan, informasi yang salah dan informasi yang dimanipulasi di media sosial, sebagai ancaman kesehatan publik global. Selanjutnya Larson melihat media sosial membantu menghubungkan orang-orang dengan pengalaman serupa, namun media sosial juga membawa orang dalam jebakan yang signifikan (Juditha, 2020). Hal ini sangat memberikan pengaruh signifikan pemahaman masyarakat tentang COVID-19.

Sebuah FGD dilakukan kepada para praktisi dan peneliti oleh CSIS Jurnal IImu Sosial dan Humaniora | 61 
Indonesia menghasilkan temuan bahwa mayoritas partisipan diskusi mengatakan bahwa mereka tidak percaya dengan informasi yang disampaikan oleh pemerintahpusat terkait kasus COVID-19 (Idris et al., 2020). Ketidakpercayaan tersebut disebabkan karena sejak awal kemunculan pandemi ini pemerintah seakan menyepelekan dengan tetap membuka kedatangan WNA ke Indonesia. Faktor lainnya seperti ketidakjelasan data juga menjadi masalah. Pemerintah juga dianggap tidak peka terhadap respon masyarakat terhadap kebijakan lockdown, dll. Selain itu ketidakseragaman informasi antara pemerintah pusat dan daerah juga menambah menurunnya tingkat kepercayaan masyarakat terhadap COVID-19.

Informasi

menyebabkan antarmasyarakat. Di minggu pertama WFH pertengahan bulan Maret lalu, disaat pemerintah belum mengumumkan kewajiban pakai masker, peneliti sempat pergi ke pasar untuk membeli kebutuhan sehari-hari. Di pasar tersebut peneliti menjadi pusat perhatian warga sekitar karena memakai masker. Mereka mendapatkan informasi jika masker hanya dipakai untuk yang sakit saja. Padahal masker adalah sarana untuk menjaga. Dengan pemakaian masker paling tidak meminimalisir ketidaksadaran orang dalam menyentuh muka (mata, hidung dan mulut) yang merupakan akses masuknya virus ke tubuh manusia. Dengan contoh berikut menegaskan bahwa disinformasi akan menyebabkan ketidakpahaman masyarakat akan COVID-19 yang sedang mewabah.

Pemahaman juga tidak berkembang karena pengabaian akan informasi yang masuk. Peneliti mengamati tentang postingan perkembangan COVID-19 daerah yang di posting di Facebook Group, tidak jarang warga yang justru jengah dan enggan melihat informasi tersebut sampai berkomentar tidak baik. Mereka seakan bosan akan pemberitaan tentang COVID-19 ini dan meminta admin untuk berhenti memposting informasi tentang perkembangan kasus COVID-19 di daerah agar tidak mengganggu imun mereka karena stres. Sebenarnya yang salah bukan informasinya, namun persepsi dan kemampuan masyarakat yang berbeda dalam mencerna informasi yang masuk.

Tidak semua warga masyarkat bisa menyerap informasi yang masuk dengan bijak. Beberapa justru ada yang menolak mentah-mentah terhadap informasi tersebut. Hal itu bisa terjadi karena sudah merasa cukup informasi yang didapatkan. Sejak munculnya informasi di media daring, banyak orang yang seolah-olah merasa tahu banyak hal atas apa yang terjadi. Taro Greenfiels dalam "Faking Cultural Literacy" (2014) menyatakan bahwa membaca dan mengobrol secara online 
membuat orang-orang menjadi seolaholah mengalami, melihat, membaca, dan menonton. Dari hal itu kemudian orang merasa hanya perlu mengetahui dan punya pendapat, sehingga merasa mampu terlibat dalam percakapan itu (Wulansari, 2019). Hal ini disebut sebagai pengetahuan palsu dan awal dari ketidaktahuan.

Tom Nichols dalam "The Death of Expertise: The Campaign against Established Knowledge and Why it Matters" (2017) membuka analisanya dengan argumen bahwa setiap orang tak akan mampu menjadi multi-kognitif atau mengetahui segala macam topik secara universal. Nichols kemudian membedakan antara pakar, profesional, ahli, atau intelektual dengan orang awam. Seorang intelektual adalah mereka yang setidaknya memiliki empat perpaduan kriteria, yaitu pendidikan, bakat, pengalaman, dan pengakuan dari rekan sejawat (Yoo, 2018).

Gerald Graff 2001 dalam "Hidden Intellectuals" menjelaskan bahwa ada kecenderungan di mana semua orang menganggap bahwa potongan info di media dapat menjadi rujukan (Wulansari, 2019). Hal ini mengakibatkan orang menganggap kemampuannya tak terbatas dan memiliki kemampuan laten yang lebih banyak. Implikasinya adalah orangorang merasa bahwa dapat menjadi pakar dalam semua hal. Dari definisi di atas merupakan cikal bakal dari rendahnya pemahaman masyarakat akan COVID-19 ini. Dari potonganpotongan informasi yang mereka dapatkan di media massa, mereka olah sedemikian rupa sehingga menganggap mereka memiliki kemampuan dan ilmu pengetahuan yang cukup akan masalah tersebut. Ibarat gelas yang penuh, mereka menolak jika ada informasi baru yang masuk yang bisa jadi justru lebih penting bagi pengetahuannya.

\section{Rendahnya Partisipasi Masyarakat dalam Ikut Serta Upaya Pencegahan COVID-19}

Semua aturan yang sudah dibuat oleh pemerintah akan sia-sia apabila tidak diikuti dengan patuh oleh masyarakat dalam menjalankannya. Seperti yang sudah digembargemborkan oleh berbagai media tentang protokol kesehatan yang harus dipatuhi seperti kewajiban memakai masker, jaga jarak, tidak keluar rumah, rajin cuci tangan dan pola hidup sehat sudah harus dijiwai oleh seluruh elemen masyarakat. Keterpaduan antara aturan dan pelaksanaan di lapangan menjadi kunci akan suksesnya pencegahan COVID-19 ini.

Pelaksanaan kebijakan pemerintah sebagaimana telah diatur dalam UU No. 4 Tahun 1984 tentang Wabah Penyakit Menular, mensyaratkan keterlibatan masyarakat secara aktif, seperti: masyarakat patuh terhadap imbauan agar tetap di rumah, ikut serta dalam aktivitas pencegahan penyebaran di lingkungan masing- 
masing dan ikut memberi sumbangan materi maupun tenaga sukarela. Tanpa partisipasi masyarakat, tujuan pelaksanaan kebijakan tersebut tidak akan tercapai dengan baik (Mulyadi, 2020).

Berbagai struktur dan dinamika masyarakat yang berlapis-lapis, berakibat pada partisipasi masyarakat terhadap pelaksanaan aturan menjadi bervariasi. Tidak bisa dipungkiri bahwa ada pengaruh dari faktor internal dan faktor eksternal dalam partisipasi masyarakat tersebut. faktor internal seperti tingkat kecerdasan sangat berpengaruh pada partisipasi masyarakat. Dari informasi yang ia dapatkan tentang pencegahan virus, apabila ia mampu mengolah informasi dengan cerdas, dia akan melakukan aksi yang cerdas pula. Sebagai contoh, dia akan menyadari tentang dirinya sendiri dahulu. Misalnya ketika dia tidak bisa melaksanakan WFH karena dia bekerja di sektor vital, maka ia akan melengkapi dirinya dengan pelindung kesehatan seperti pemakaian masker yang benar, membawa hand sanitizerke kantor, menjaga jarak, dll. selain itu, pengalaman juga akan menentukan banyak hal. Banyak warga yang menegasikan virus ini antara ada dan tidak ada. Ada yang menganggap bahwa virus ini adalah konspirasi. Bahkan tragisnya ada yang menganggap bahwa virus ini tidak ada. Mereka berpendapat bahwa mereka yang sakit tersebut meninggal karena ketakutan akan adanya informasi yang menyeramkan. Beberapa berpendapat bahwa mereka yang sembuh harus membagikan obatnya untuk masyarakat umum. Mereka menyuarakan di media sosial agar pemerintah tidak menyembunyikan informasi obatnya. $\mathrm{Hal}$ ini tentu sangat fatal karena menunjukkan disinformasi yang sangat jauh karena dipastikan bahwa sampai saat ini belum ada obat yang ditemukan untuk menyembuhkan COVID-19. Yang bisa dilakukan hanya meningkatkan imuntas tubuh dan menjaga kesehatan tentunya dengan mematuhi protokol kesehatan.

Nichols (2017) menyatakan frasa "The Death of Expertise" (matinya kepakaran) yang merujuk kepada akar dari segala kebebalan orang awam yang mengalami "Efek Dunning-Kruger" bahwa "semakin bodoh Anda, semakin yakin bahwa Anda sebenarnya tidak bodoh". Temuan utamanya bahwa "Mereka bukan hanya salah dalam menyimpulkan dan membuat pilihan, inkompetensi juga merampas Era Kebebalan: Penyebaran Pengetahuan Palsu dan Kematian Intelektualitas kemampuan mereka menyadari kesalahan tersebut (Mulyadi, 2020).

Dengan pola pikir seperti itu mustahil protokol kesehatan dapat dilakukan dengan disiplin oleh masyarakat. Beberapa bukti menyebutkan penolakan "nalar" atas adanya wabah ini. Mereka dengan lantang menyatakan bahwa urusan hidup mati sudah 
digariskan oleh Tuhan sehingga tidak perlu cemas. Hal ini justru menolak logika. Memang benar bahwa hidup mati manusia sudah di tangan Tuhan, akan tetapi manusia wajib berikhtiar untuk melawan wabah ini dengan segenap usaha dan daya upaya yang ada. Kompleksnya masalah, minimnya pengetahuan, ketidakmampuan mencerna informasi, rendahnya pengalaman dan pengetahuan, kecacatan logika berpikir sangat erat kaitannya terhadap reaksi masyarakat atas permasalahan sosial.

\section{Kondisi Ekonomi Masyarakat}

Kondisi ekonomi masyarakat juga memiliki pengaruh terhadap persepsi dan aksi masyarakat terhadap COVID-19 ini. Kondisi ini disebabkan oleh empat faktor. Faktor yang pertama adalah menghilangnya kesempatan kerja atau pemutusan hubungan kerja. Sebagian besar masyarakat pedesaan bekerja di sektor industri dan buruh bangunan. Dengan adanya COVID-19, banyak tempat kerja mereka pun tutup. Bahkan mereka yang merantau di kota besar seperti Jakarta atau Surabaya terpaksa pulang kampung karena di kota mereka kehilangan pekerjaan sedangkan kebutuhan semakin banyak. Dengan sedikitnya pekerjaan yang ada sangat berpengaruh pada kondisi ekonomi mereka. Faktor yang kedua adalah melemahnya usaha mikro masyarakat. Beberapa usaha rumahan terpaksa berhenti beroperasi karena daya beli masyarakat yang menurun. Dampak dari lemahnya ekonomi membuat masyarakat harus membeli barang atau kebutuhan yang benarbenar mendesak dan primer sehingga usaha tersier semakin sepi. Bahkan mereka ada yang sampai menjual mesin usaha untuk membeli kebutuhan harian. Faktor yang ketiga adalah rendahnya daya beli masyarakat. Para istri harus benar-benar menata keuangan dengan sedemikian rupa karena pendapatan yang tidak menentu sedangkan pengeluaran harian tetap terjadi. Faktor yang keempat adalah rendahnya jaminan sosial terhadap kondisi ekonomi masyarakat. Mereka tidak memiliki dana darurat yang cukup untuk menghadapi wabah ini. Tentu hal ini bisa menjadi pelajaran bagi masyarakat tentang pentingnya memiliki dana darurat. Seperti diungkapkan oleh Reimann (2009) "Many of those who could become impoverished because of the COVID-19 crisis are not receiving social protection unless programs are expanded, and informal workers without access to unemployment insurance and other support to the formal economy are particularly at risk".

Keempat faktor tersebut yang mempengaruhi kondisi ekonomi masyarakat yang bermuara pada reaksi terhadap COVID-19 ini. Beberapa masyarakat terpaksa tetap beraktivitas di luar rumah karena untuk mencukupi kebutuhan hidupnya. Mereka adalah pekerja harian yang memiliki 
pendapatan harian sehingga jika tidak bekerja pada hari itu, mereka tidak ada pendapatan untuk mencukupi kebutuhan hidupnya.

Mayoritas penduduk desa bekerja sebagai buruh bangunan, buruh persawahan, pedagang, dan pekerja lepas lainnya, sehingga perekonomiannya ditunjang dengan pekerjaan harian tersebut. Berdasarkan hasil observasi, kebanyakan mereka tetap beraktivitas di sawah seperti biasanya. Selain itu, mereka yang keluar rumah adalah ibu-ibu yang pergi ke pasar atau membeli sayuran di dekat rumahnya. Hal ini tidak bisa dihindarkan karena mereka tidak bisa menyetok makanan di rumah karena mereka mendapatkan uang untuk membeli bahan makanan secara harian sehingga belanjanya pun harian.

Tidak Adanya Aturan yang Mengikat

Dari hasil observasi, hanya $54.9 \%$ dusun atau desa yang memiliki peraturan yang mengikat bagi warganya. Hal ini penting karena setiap masyarakat berbeda karakteristiknya. Berdasarkan Peraturan Pemerintah Nomor 72 Tahun 2005, bahwa Pemerintahan Desa adalah penyelenggara urusan pemerintahan oleh Pemerintah Desa dan Badan Permusyawaratan Desa dalam mengatur dan mengurus kepentingan masyarakat setempat berdasarkan asalusul dan adat istiadat setempat yang diakui dan dihormati dalam sistem Pemerintahan Negara Kesatuan
Republik Indonesia (Saiful, 2014). Dari pemerintahan desa tersebut, aturan bisa berupa hal yang spesifik dan khusus dengan mempertimbangkan kondisi sosial masyarakat tertentu.

Arus informasi dari peraturan desa pun lebih efektif karena dilakukan dengan memperhatikan kondisi desa. Sebagai contoh, pengumuman tentang aturan COVID-19 dilakukan dengan cara yang berbeda-beda. Di satu daerah menggunakan pengeras suara di masjid karena tidak semua warga terjangkau internet. Contoh lainnya menyatakan bahwa perangkat desa terpaksa menyebarkan aturan atau himbauan tertulis secara door to door ke rumahrumah warga agar semua warga mendapatkan informasi yang sama. Perbedaan perlakuan inilah yang mempengaruhi persepsi dan aksi masyarakat dalam menghadapi COVID19. Ada daerah yang longgar terhadap pendatang namun ada daerah yang benar-benar melaksanakan karantina di daerah desa dengan dijaga ketat relawan COVID desa. Hal ini seringkali menjadi polemik dalam bermasyarakat karena aturan yang berbeda sebab aturan di tingkat atas tidak mengikat dengan sanksi yang tegas atau hanya bersifat imbauan. Seperti pada klausa "Jangan keluar rumah jika tidak mendesak." Hal ini tentu berbeda-beda persepsi yang muncul dari masyarakat. Kata "mendesak" tentu sangat subjektif. Ada warga yang harus berjualan di pasar untuk memenuhi kebutuhan Jurnal IImu Sosial dan Humaniora | 66 
hidupnya. Hal ini bisa dikatakan mendesak. Ada warga yang terpaksa keluar rumah untuk membeli beberapa kebutuhan juga bisa dikatakan mendesak. Melihat fenomena ini diperlukan adanya aturan yang benarbenar mengikat dan jelas peruntukannya. Misalnya sektor apa saja yang boleh beraktivitas di luar rumah atau protokol wajib yang harus dipenuhi jika keluar rumah. Jika tidak dipatuhi, akan ada sanksi yang tegas. Dengan demikian masyarakat akan disiplin menjalankan protokol kesehatan.

\section{SIMPULAN DAN SARAN}

Hasil penelitian menyebutkan bahwa 56.9\% masyarakat masih beraktivitas dan berkumpul di luar rumah dan hanya $13.7 \%$ yang konsisten menggunakan masker. Sebanyak $31.4 \%$ rumah juga tidak menyediakan sarana cuci tangan. Berbagai faktor yang mempengaruhi persepsi masyarakat tersebut adalah: kurangnya pemahaman akan COVID-19, rendahnya partisipasi masyarakat untuk ikut serta dalam upaya pencegahan COVID-19, dan tidak adanya aturan yang mengikat. Berdasarkan hasil penelitian, peneliti merekomendasikan agar ada sinergitas antar seluruh elemen masyarakat dan pemerintah untuk bekerja sama meningkatkan kesadaran masyarakat dalam mematuhi protokol kesehatan.
Pemerintah desa juga harus membuat satgas COVID-19 desa sebagai leading sector penanggulangan COVID-19 di masing-masing desa. Karang taruna sebagai organisasi kepemudaan di desa harus aktif sebagai jembatan informasi yang terpercaya untuk masyarakat. Selain itu, aturan pemerintah desa juga harus dibuat dengan bahasa yang mudah dipahami oleh masing-masing warga desa. Jika sinergitas seluruh elemen masyarakat di desa baik, pencegahan wabah COVID-19 akan maksimal.

\section{DAFTAR PUSTAKA}

Abdul, A. R., Nuraini, A., Elisa, K., \& Iman, S. (2020). Faktor-Faktor Psikososial dari Ketidakpatuhan Masyarakat pada Masa Pandemik. Artikel, 19, 1-10.

Adib Auliawan. (2020). Hari Kedua Lebaran, Pasien Positif Covid-19 di Indonesia Capai 22. https://www.ayosemarang.com/rea d/2020/05/25/57570/hari-kedualebaran-pasien-positif-covid-19-diindonesia-capai-22750-kasus

Arifin, H. S., Fuady, I., \& Kuswarno, E. (2017). Analisis Faktor yang Mempengaruhi Persepsi Mahasiswa terhadap Keberadaan Perda Syariah di Kota Serang. Jurnal Penelitian Komonikasi Dan Opini Publik, 21(1), 88-101.

Buana, D. R. (2020). Analisis Perilaku Masyarakat Indonesia dalam Menghadapi Pandemi Virus Corona (Covid-19) dan Kiat Menjaga Kesejahteraan Jiwa. 
SALAM: Jurnal Sosial Dan Budaya Syar-I, $7(3)$. https://doi.org/10.15408/sjsbs.v7i3. 15082

Detik.com. (2020). Kapan Sebenarnya Corona Pertama Kali Masuk RI? In News.Detik.Com (p. 1). https://news.detik.com/berita/d4991485/kapan-sebenarnyacorona-pertama-kali-masuk-ri

Devi Pramita Sari, \& Nabila Sholihah 'Atiqoh. (2020). Hubungan Antara Pengetahuan Masyarakat Dengan Kepatuhan Penggunaan Masker Sebagai Upaya Pencegahan Penyakit Covid-19 Di Ngronggah. Infokes: Jurnal Ilmiah Rekam Medis Dan Informatika Kesehatan, 10(1), 52-55. https://doi.org/10.47701/infokes.v1 0 i1.850

Djalante, R., Lassa, J., Setiamarga, D., Sudjatma, A., Indrawan, M., Haryanto, B., Mahfud, C., Sinapoy, M. S., Djalante, S., Rafliana, I., Gunawan, L. A., Surtiari, G. A. K., \& Warsilah, H. (2020). Review and analysis of current responses to COVID-19 in Indonesia: Period of January to March 2020. Progress in Disaster Science, 6, 100091. https://doi.org/10.1016/j.pdisas.20 20.100091

Fillaili, R., \& Tamyis, A. R. (2020). Melalui Komunikasi Risiko yang Efektif pada Masa Pandemi COVID-19. SMERU Catatan Kebijakan, 7.

Hasrul, M. (2020). Aspek Hukum Pemberlakuan Pembatasan Sosial
Berskala Besar (PSBB) dalam Rangka Penanganan Corona Virus Disease 2019 (COVID-19).

Idris, I. K., Gismar, A. M., \& Ardiyanto, E. (2020). Kepercayaan Terhadap Informasi dari Pemerintah di Masa Pandemi COVID-19. Https://Csis.or.ld/, 1-5. https://csis.or.id/publications/keper cayaan-terhadap-informasi-daripemerintah-di-masa-pandemicovid-

19/\%0Ahttps://csis.or.id/publication s/kepercayaan-terhadap-informasidari-pemerintah-di-masa-pandemicovid-19

Juditha, C. (2020). People Behavior Related To The Spread Of Covid19's Hoax. Journal Pekommas, 5(2), 105. https://doi.org/10.30818/jpkm.2020 .2050201

Mulyadi, M. (2020). Partisipasi Masyarakat Dalam Penanganan Penyebaran Covid-19. Info Singkat, Pusat Penelitian Badan Keahlian DPR RI, XII(8), 13-18.

Novira, N., Iskandar, R., \& Bahraen, R. (2020). Persepsi Mayarakat akan Pentingnya Social Distancing dalam Penanganan Wbah Covid19 di Indonesia. Jurnal Kependudukan Indonesia, 2902, 27-32.

https://ejurnal.kependudukan.lipi.g o.id/index.php/jki/article/view/573

Putri, G. S. (2020). WHO Resmi Sebut Virus Corona Covid-19 sebagai Pandemi Global. Kompas. https://www.kompas.com/sains/rea d/2020/03/12/083129823/who-

Jurnal IImu Sosial dan Humaniora | 68 
resmi-sebut-virus-corona-covid-19sebagai-pandemi-global

Reimann, A. (2009). The Economic and Social Impact of Coordination. European Journal of Social Security, 11(1-2), 133-141. https://doi.org/10.1177/138826270 901100106

Rohmaul Listyana \& Yudi Hartono. (2015). Persepsi dan Sikap Masyarakat Terhadap Penanggalan Jawa dalam Penentuan Waktu Pernikahan (Studi Kasus Desa Jonggrang Kecamatan Barat Kabupaten Magetan Tahun 2013). Jurnal Agastya, 5(1), 118-138.

Saiful. (2014). Eksistensi Peraturan Desa Pasca Berlakunya UndangUndang Nomor 12 Tahun 2011. 2(c), 1-43. https://doi.org/10.16526/j.cnki.114762/tp.2014.11.051

Sitohang, M. Y., Rahadian, A. S., \& Prasetyoputra, P. (2020). Indonesian Community Initiative in the Early Phase of the Covid- 19 Pandemic: a Health Development Strategy. Jurnal Kependudukan Indonesia, 2902(Edisi Khusus Demografi dan COVID-19), 33-38.

Sudarno, A. (2020). Bima Arya Ungkap Warga Bogor yang Gunakan Dana Bansos Beli Baju Lebaran - News Liputan6.

https://www.liputan6.com/news/rea d/4258935/bima-arya-ungkapwarga-bogor-yang-gunakan-danabansos-beli-baju-lebaran

Wulansari, A. D. (2019). Era Kebebalan: Penyebaran Pengetahuan Palsu dan Kematian Intelektualitas. 1(7).

Yoo, H. (2018). The Death of Expertise: The Campaign Against Established Knowledge and Why It Matters by Tom Nichols. Journal of Intellectual Freedom and Privacy, 2(3-4), 35. https://doi.org/10.5860/jifp.v2i34.6483 